Title: Moral outrage: Social workers in the Third Space

Title: Moral outrage: Social workers in the third space

Published in

Fronek, P., \& Chester, P. (2016). Moral outrage: social workers in the Third Space. Ethics and Social Welfare, 10(2), 163-176. doi:10.1080/17496535.2016.1151908

\title{
Abstract:
}

Injustice is at odds with social work's mandate to promote social justice, human rights and ethical responsibility. In nations such as the UK, Australia and the US, ideologies of the far right exert strong influences on social policy. In this critical commentary, we argue that shifts from welfare states to privatisation, the return of the deserving and undeserving as 'strivers' and 'shrivers', 'lifters' and 'leaners', and policies that violate the human rights of refugees and other disenfranchised groups have activated moral outrage within the social work profession. Moral distress, ethical responsibilities and, for some, fears of complicity when unjust policies become practice, suggest that a moral response is required. A new form of online activism in a Third Space has emerged that juxtaposes traditional social work activism in ways that are responsive to social work's moral imperatives, and is a panacea for moral outrage within a global context. Such actions pose ethical complexities and are not without risk. Stéphane Hessel offers a framework to understand how peaceful civil disobedience and radical approaches are legitimate expressions of moral outrage that transcend indifference and despair. We explore the new social work activism emerging in the Third Space drawing from Hessel’s philosophies.

Key words: moral outrage, resistance, activism, cyberspace, Third Space 


\section{Moral outrage: Social workers in the third space}

The far right is exerting increasing political influence in Western democracies to the point where rhetoric and ideological approaches to welfare, minorities and special needs groups appear almost indistinguishable between nations. Economic and social inequalities are increasing alongside a rise in social problems attributed to the parasitic and undeserving by the political far right (Hills 2015; Jones 2011; Wilkinson and Pickett 2010). The cumulative effects of shifts from welfare states to privatisation and to concepts of individual responsibility that exclude the structural factors inherent in disadvantage; the monopolisation and globalisation of traditional media ownership and their influence over public discourse; the return of concepts of 'deserving' and 'undeserving' in the form of 'strivers' and 'shrivers' and 'lifters' and 'leaners'; and policies that are unjust and violate the human rights of refugees and other disenfranchised groups have activated moral outrage for human rights activists, international organisations, and social workers (Gilbert 2015; Gilens 2012; Harris 2014; Hills 2015; Jones 2011; Kerr 2014; Robinson 2014; Williams and Briskman 2015).

Although the development of civil societies, global economics, and information technology is supposed to cause political systems to become more democratic and produce benefit for all citizens (Armer and Katsillis 2001), the reverse is evident in many Western democracies where democratic process appears selective depending on who influences and who benefits, and how 'civil' society is becoming is debatable. For social workers, the values of social justice and the commitment to human rights are enshrined in many codes of ethics and demand attention where they are violated even though the ethical foundations of our 
profession have been undermined by the 'unprecedented centralisation of wealth and power and the institutionalisation of a market oriented philosophy throughout the world' (Reisch 2013, p.67). Reisch (2013) describes this as a managerial approach that is narrow and ahistorical, oriented toward empiricism and fiscal accountabilities that force social workers to renegotiate their relationships with clients, the state and the market. For example in the UK, Garrett (2008; 2014) describes tensions between social work values especially social justice in child protection and in welfare where social workers' relationships with the unemployed in a meritocratic 'work society’ is changing. Shaped by political restrictions, managerialism, fragmentation and lack of resources these tensions are forcing social workers into uncomfortable positions.

In 2010, ninety-three year old Stéphane Hessel, activist, diplomat, and secretary of the commission that drafted the Universal Declaration of Human Rights (1948), wrote a manifesto, A Time for Outrage, drawn from his extraordinary experiences over a very long lifetime (Hessel 2011, 2012; United Nations 1948). Like Viktor Frankl, author of A Man’s Search for Meaning (2004), Hessel (2012) survived a Nazi concentration camp, experienced inhumanity, knew outrage and the consequences of inaction by those who could act but did not. Frankl and Hessel wrote about the importance of hope in the face of injustice and despair, and for Hessel, the ultimate hope is to triumph over the despair that leads to outrage in the first place. Just and justified contemporary resistance provides the means to do so. He explained why we should care when he said:

'It's the duty of all of us to ensure our society remains one of which we are proud, not a society wary of immigrants and intent on their expulsion or a society that disputes the welfare state or in which the media is controlled by the wealthy' (Hessel 2011, 2). 
Using this yardstick to examine the societies in which many of us live, we cannot in good conscience be proud of them, particularly in relation to displaced and marginalised peoples. Western societies governed according to conservative ideologies are not alone in hardened attitudes towards refugees. Our governments are intent on their expulsion, preventing their entry and abandoning them at sea, and politicians boast about what is nothing more than a concentration camp renaissance (Australian Human Rights Commission 2014; Robinson 2014). The big media corporations, owned by the few, assist in this shaping of public discourse on this and many other issues. When language changes - for example from 'asylum seeker' to 'illegals', from the unemployed, people with disabilities and the aged to 'leaners'meanings are altered to support ideological positions and political interests and these shifts objectify those people most in need and deem them less worthy.

Hessel’s (2011) framework offers a means by which despair and outrage about injustice can be mitigated by translating it into action. For Hessel, this action was about the setting down and implementation of human rights. For these authors, the response to neoliberal approaches to people in need is outrage, but armchair outrage is insufficient for resistance against injustice and breaches of human rights. According to Hessel (2012) we must first examine our outrage and reflect on it because outrage can simply be stupid and dangerous and we must understand the difference (Hessel 2012). He reminds us that unhealthy emotions contain hatred. Because of this, outrage should be tempered by rationality and knowledge. Furthermore, to be justified, outrage once examined must then translate into action and a desire to engage. Just as the granting of human rights is an important starting point, granting rights by itself is not enough to prevent breaches of those rights (Smart 1989). Similarly the state of outrage is by itself insufficient. The challenge then, is how to transcend from personal outrage to social influence and the rejection of the unacceptable through moral and ethical actions. It is those people wrongly labelled as "leaners" and "shrivers" and those simply not 
valued who are most affected by inequality and are a concern of social work. In Australia, for example, "leaners", the target of government reforms, are those people in receipt of disability support, under thirties receiving income support, aged pensioners, Indigenous peoples, refugees and asylum seekers to name a few groups adversely affected by the ideology of Abbott's coalition government and deemed a burden on society (ACOSS, 2015). Under this regime, fault lay with the individual and structural contributors to poverty and marginalisation are ignored. Inhumanity, the gap between what people need and the availability of resources to meet those needs, and concerns that social work itself is being subsumed and controlled by neoliberal politics are occurring alongside welfare reforms that compound problems rather than address them, each a source of distress for social workers (Lee 2014).

This commentary draws on Hessel's philosophies that legitimise outrage and justified, reflected-on resistance. We propose that a merged social work identity, formed in cyberspace, allows resistance to be exercised in ways that are responsive to social work's moral imperatives, and adds to traditional social work activism and critical practice in a changing world. Actions ranging from expressing outrage to radical action offer means of soothing moral outrage and despair in a virtual arena. The third space is theorised as a conceptual zone (Bhabha 1990; English 2005; Hübinette 2004; Routledge 1996; Whitchurch 2008) where communities of social workers can perform new hybrid identities, and offers potentiality for outraged social workers, as professionals and activists, to engage in dynamic activism in cyberspace. However, ethical challenges accompany such online activism.

\section{Social work and activism}

Social work can be viewed as a dissenting profession because in order to uphold its mission, social workers are agents of change obligated to address social injustice and breaches of 
human rights where they occur (Cooper 1977; Dean 1977). Reeser (1991, 7) defined social activism as 'attitudes that support and behaviours that attempt to influence the social distribution of status, power, and resources'. This cognizance of social and economic disparities has created ongoing debates about how radically active social work should be and whether the focus of social work should be on the individual and that individual's fit in society or a broader focus on the redistribution of power and resources. Although there is general acceptance that both are needed there are still tensions and criticisms between proponents of both positions and no universal agreement on how a dual focus can be achieved in practice (Healy 2001, Mizrahi and Dodd 2013; Weiss 2003). The degree to which social workers are politically engaged has varied throughout its history (Swank 2012), shaped by the social policy environment in which it is practised and the outrage its impact produces.

Critical social work that shares much with Hessel has its radical roots in the 1960s and 1970s when outrage was generated by gender inequalities, racial discrimination, anti-war sentiments and the rights of disadvantaged groups. By the end of that decade some social workers, already concerned about the profession's propensity towards individualism were calling for a return to radicalism and the collective (Dean 1977). Dean (1977) reminded social workers that part of our mission was to change social systems and, in particular, challenge policies that do not benefit people and fail to address equality. There were early predictions that the professionalisation of social work would mean social action would be abandoned in exchange for professional status (Benthrup 1964). Addressing these early concerns, Reeser's (1991) US study conducted in the 1980s found weak evidence that rather than opposing all forms of activism, career minded professionals tended to prefer conservative methods of action such as visiting public officials.

Fifty years after Benthrup expressed concern, Lee (2014) posited that social work has become so consumed by the neoliberal agenda of marketisation that resistance is no longer exercised 
between organisations or social workers and the state. Rather if it exists at all, resistance is exercised locally between front-line workers and managers in an attempt to preserve the values that prioritise their clients and continue to advocate for them. Lee (2014) suggests old forms of radicalism are dead and at best draw attention to inequalities but lead nowhere. However, it could be said that drawing attention to inequalities is not a wasted endeavour. It should also be noted that community social work has always made a major contribution to activism and policy change by addressing structural disadvantage at the grassroots. Radical social work practice in a range of fields is alive and well in many countries offering a valid response to injustice, breaches of rights and inequalities (Calhoun, Wilson and Whitmore 2014; Ioakimidis et al. 2013; Lam and Tse, 2013; Moth, Greener, and Stoll, 2015; Smith, 2015). Ferguson and Lavalette (2007, p.58, 63) provide examples of social work resistance that joins with consumers - namely 'new social welfare movements' such as disability and mental health service user organisations in the U.K., and movements that act against neoliberal globalisation and the state of contemporary social work that is constrained by market-based welfare and 'moral authoritarianism'. Rather than slowly retreating from our values and ultimately surrendering to the conservative political agenda as Lee (2014) suggests is inevitable, Greenslade, McAuliffe and Chenoweth (2014) legitimised an alternative resistance enacted at the coalface in a covert form of radical action that eased tensions for practitioners. Where social workers identified a lack of congruence between their values and their employing organisation, covert actions such as turning a blind eye mitigated against distress that can cause social workers to leave their jobs or burnout.

Perhaps it is the profession's adaptability and practical qualities that enables its survival. This very reflexivity also necessitates constant scrutiny to resist the pressures of the neoliberal creep that has threatened to side shift social work's mission and erode its values through our very co-operation with it. It can be argued that restrictions placed on activities by employers 
and avoiding the derision and blame as occurred in the Baby P case in the UK (Jones 2014) might exist and can impede more radical approaches in modern social work. The death of Baby P, seventeen month old Peter Connelly, in the UK was used by the Labour government and the Tory opposition to scapegoat individual social workers and the profession generally in an extraordinary political and media witch-hunt. The child's death was attributed to professional incompetence and a generalised inability to protect children. Patrick Butler (Jones 2014, p. ix) described it as collective madness, media exploitation and political opportunism. The fallout was a further shift away from professional autonomy to greater government and legislative control over child protection and increased aversion to risk and media criticism. Social workers, like everyone else, like to keep their jobs. While saying this, the flexibility and practicality that has seen social work make compromises has also opened the way for radical approaches responsive to the needs of people in contemporary sociopolitical environments with the resurgence of grassroots organisations and a radical re-birth (McKendrick and Webb 2014). We argue that breaches of human rights and injustice are so widespread and the targeting of the vulnerable has heightened to such intensity that social workers need to also intensify their resistance. The Third Space offers a zone where social workers are enacting resistance as individuals and as a global social work collective in a variety of ways.

\section{The Third Space}

The theory of the Third Space offers a post-colonial perspective (Bhabha 1990; Khan 1998) on social work resistance and social work as a profession that has been colonised by neoliberal, conservative politics. Action in the Third Space challenges binaries produced in this oppression - the splitting of social work into 'professional' social workers as neutral, apolitical and concerned only with delivering services to the individual within society, and activists considered idealists sitting apart from mainstream social work - both being 
constrained by predetermined conceptualisations that define their agency in activism. Social workers in cyberspace create a Third Space of ambiguity where individually, collectively, locally and globally, a hybrid identity of the social work professional-activist is formed, reformed and adaptable and relevant. It offers a zone where outrage can be expressed with rationality and knowledge and resistance to inhumanity and injustice can be exercised. In this zone social workers are more than agents of the state and if restrictions on activism exist in daily practice, they may be modified in this space. As Lorenzetti (2013) stressed, in social work there is ‘no apolitical fence to straddle’ (2013, 454).

Although on-line activism has been researched (McNutt 2006) and a simple google search shows that multiple networks of connected social workers are expressing outrage as professional-activists, little theorising has been conducted on social work identities in cyberspace. The Third Space theorised in this paper is where social work academics and practitioners, both traditionally 'professional' and activist, become a professional-activist hybrid made unique by its on-line presence. Arbitrary divisions between professional and activist and geographical boundaries dissolve. Given the existing literature on hybrid identities in other contexts (Flood, Martin, and Dreher, 2013 Yerbury and Burridge, 2013), it is likely that social workers will view their multiple identities differently. Some may reimagine a merged identity as a comfortable fit beyond the Third Space while others may move backward and forward between that of their usual practitioner or academic role and the hybrid identity formed with others on-line.

Essentially the formation of the professional-activist identity in the Third Space allows for the rejection of neoliberal colonalisation - the slow creep undermining the profession and the targeting of the people with whom we work. Actions can be purposeful, focused on organising resistance or be more abstract, fluid and organic. It enables action outside traditional structures offering alternative ways to influence much like Deleuze and Guattari’s 
(1981) rhizomes. Using this analogy, we only need to think of the ginger plant or bamboo. No matter how hard we try to contain it, chop off the roots, put up barriers or even poison it, the plant seems to reappear somewhere else. Likewise, the movement of ideas in the Third Space can reject a central point of order and instead describe a flow of social action that can connect at different points and if connections are broken or blocked, they reappear elsewhere. Thus messages of resistance are spread through such connections.

Action in cyberspace, therefore allows for the spread of targeted messages in work with clients or service users towards change, or to potentially influence the political by addressing skewed representations of the profession in public discourse that is perpetuated by the media in some countries. The internet offers the potential for an unparalleled distribution of alternative messages and the tools for social workers to act. Robbins and Singer (2014) provided a comprehensive list of social media tools from short (e.g. Twitter and Facebook) and long form writing (e.g. blogging) to videos (e.g. Youtube) and podcasts. Soon and Kluver (2014) pointed out that although actions such as blogging are highly individual a larger collective network results from blogging activities. Professional-activists are connecting and expressing themselves on all available media platforms from Twitter and Facebook to blogging and podcasting (AUTHOR 2015). Some examples of activist social work networks are The Social Work Action Network, SWAN, (http://www.socialworkfuture.org/), Macro Social Work Student Network, MSWSN, (http://www.mswsn.org/), Social Work and Health Inequalities Network, SWHIN, (http://blogs.coventry.ac.uk/swhin/). Other websites such as The Social Work Helper (http://www.socialworkhelper.com/) count amongst many others worthy of mention. Examples of activity in the Third Space from The Social Worker Helper include an article that explores the impact of austerity on American women who are already affected disproportionately by poverty and inequality (Muižnieks 2015) and another on why social workers should address economic inequalities (Lewis 2015). Both call for action. 
Many social work associations are also taking firm online positions against injustice, for example, the Australian Association of Social Workers (AASW) and the International Federation of Social Workers (IFSW) publish policy statements with regards to social justice and human rights issues such as refugees and children in detention. Increasingly social work associations like the AASW and the IFSW have profiles on platforms such as Twitter and Facebook to distribute these positions (AASW 2015; IFSW 2012). The list of individual professional-activist bloggers and communicators are too many to name.

The direction of potential influence can be conceptualised in three ways - across, upward and outward. Movement is reflexive and works towards the direction of influence and back to the professional-activist. Activism that works across can form collaborate partnerships with clients and service users for research, advocacy and practice. Working upward is intended to influence policy makers and politicians and outward seeks to influence the general public and the media. Activating outward and upward involves two motivations to influence - to educate about social issues and influence change, and to promote our own image of social work not one shaped by political forces as in the Baby P case (Jones, 2014).

Morris (2013) connected with disabled people’s movements in the UK using social media for research and activism. In India, personal technologies such as mobile or cell phones and internet access were found to be vital for engaging and activating youth who are known to be apolitical and hard to involve in collective action despite facing rising unemployment, inequality and systemic corruption at multiple levels (Vigneswara Ilavarasan 2013). In an another example, social worker Joel Izlar’s blog (http://www.izlar.ch/?p=3910) connects with other social workers and spreads activist information such the Western Regional Advocacy Project (WRAP) that leads the Homeless Bill of Rights Campaign in the U.S. and "strives to ensure that ALL people have the basic right to live where they choose without fear of harassment and criminalization”; and the US Social Forum and People’s Movement 
Assembly that is “ led by those most impacted by the current system, helps build alliances and develop action plans for our movement against all forms of oppression”.

Voices against Bigotry (http://www.voicesagainstbigotry.org/) was recently launched in Australia by human rights academics and social workers, Susie Latham and Linda Briskman, in consultation with various groups and individuals and communities. The organisation is concerned with the growing Islamophobia in Australia and the vilification of Muslims by politicians and some media and seeks to influence in the three directions. Of particular concern is the expected launch of an anti-Muslim political party in Australia assisted by international organisations and extremist Dutch politician, Geert Wilders. Others are publishing in media such as The Conversation (https://theconversation.com/au) and The Guardian (http://www.theguardian.com) and other newspapers. A practitioner recently trended on Twitter with the hashtag 'I’m a social worker because' (Schraer 2015). All these actions are important as it is not enough to only network with social workers just as writing articles for scholarly journals are unlikely to influence the general public. An awareness of online tribalism is essential when reflecting on our activism if we intend to truly influence. Influence will be limited if we only speak to those of like minds and although at times it may mean exposure to criticism and conflict, broadening the conversation may also present opportunities and perspectives previously not considered.

Online activism generally has been criticised for being ineffective and not achieving intended change. However in support of the potential impact of online activity, research is emerging that suggests politicians and governments use and do pay attention to activity in forums like Twitter and Facebook (Archer-Lean and Pavitt 2012; Grant, Moon, and Grant 2010; Hutchins, 2014; Miragliotta 2012; Williamson 2010). McNutt (2006) identifies on-line advocacy as a legitimate practice method for social work to exert influence with regard to policies and outlines how evidence-based approaches to online activities could be developed 
despite barriers such as the wide and varied influences on policy change and the dynamic nature of online activities.

Using on-line tools such as Twitter to follow politicians and journalists can be important in shaping public conversations. In Australia, politicians, or at least their advisors, are alert to criticism and are reported to spend millions on monitoring social media (Shields 2015). Large media corporations can cause shifts in societal attitudes by influencing how people think and talk about issues and although yet to be measured, social work messages can bear influence by complicating simple messages with more nuanced realities (Harris 2014; Jones 2011; Jones 2014). Few journalists understand the work of social workers. Journalists also victims of the neoliberal onslaught are always looking for stories and new angles as their access to field work in some countries is greatly reduced by budget cuts.

Due to the importance of the potential influence of online activism, its complexities, and risks and responsibilities associated with using social media tools, awareness of ethical considerations and reflections on our motives and actions are important in the Third Space.

\section{The 3 Rs - risk, responsibility and reflection}

Although ethical theory is debated and no universal position on applied ethics in social work exists, there is some consensus on core values that centre on the worth of human beings, respect and justice despite cultural and other contextual differences (Banks 2012; Congress 2012; Hugman 2008; Noble and Briskman 1996). If we claim to be ethical social workers, surely we are compelled to act in the face of injustice and breaches of human rights that devalue the worth of people. Injustice and breaches of rights do cause outrage for social workers and in our world today are no less than that experienced by Hessel (2012) during his lifetime. Activism of any kind, however, is not without risk (Flood, Martin, and Dreher 2013; McNutt 2006; Turbett 2013) and action in the Third Space is neither risk free nor distant as it 
can also involve conflict by attracting criticism, dissenting views and ethical problems such as confidentiality and dual accountabilities. Safe activity can be negotiated by utilising critical reflection and ethical decision making (Fook 2002; McAuliffe and Chenoweth 2008) and maintaining a sense of Hessel's rationality and use of knowledge despite our emotion. Therefore understanding and managing risk, our ethical responsibilities (Reamer 2012) and in engaging critical reflection on our activism as Hessel (2011) suggests is important for safe, ethical approaches. Ensuring our messages are rational and based in knowledge supports ethical practice in the Third Space.

As noted by Routledge (1996), academics hold privileged positions where contributing to public commentary is expected (Flood, Martin and Dreher 2013) whereas opportunities for radical social work actions for many practitioners employed in conservative or statutory agencies are greatly reduced. Tightening control exercised by governments that limit action perceived to be contrary to their interests is ironic given the libertarian ideologies of the far right. In Australia, recent legislation that prevents health practitioners including social workers from speaking out about the extreme and inhumane treatment of asylum seekers in detention provides one example (Briskman, Zion and Loff 2012; Farrell, 2015). Some social workers are shackled by confidentiality clauses and policies that directly prohibit online engagement. Employees are generally not free to publically criticise their organisation. Confidentiality with regard to client identities and information is usually clearly articulated in most professional codes of ethics and organisational codes of conduct. What is not so clear is how free social workers are to critique governments and their policies when they fund their employing organisations that may or may not have codes and policies that define the limits of action (Kimball and Kim 2013). Responsibility therefore unravels a complex array of dilemmas and ethical problems that must be negotiated. 
One strategy for ethical responses offered by Hessel (2011) is to temper emotion with reason and knowledge. As professional-activists we need to be clear about the source of outrage and the message we want to deliver, and to combine this with knowledge about codes of ethics, legislative responsibilities and ethical decision making. This means being thoughtful, contained, intentional and respectful in our communications especially where we have multiple accountabilities. Anecdotally, many social workers do not reveal their identities online and operate under pseudonyms. Sometimes collective action online or joining the collective through professional organisations may simply involve reposting, retweeting, liking or following, something all social workers can do that supports the activities of those social workers and organisations who can act more freely.

Fang et al. (2014) and Duncan-Daston, Hunter-Sloan, and Fullmer (2013) draw attention to risks associated with social media and higher education particularly the separation of the personal and professional and the distinctions between public and private. It could be argued that the professional-activist should not find it too difficult to respect ethical obligations such as client confidentiality in public spaces. However, separating the personal and professional or the personal and public does not sufficiently address the ethical concerns that using internet technologies pose when communication is instantaneous and boundaries between the personal and professional are not clearly defined. In Australia, bloggers are not given the same protections as journalists with regard to what constitutes public interest as is the case in the U.S. and New Zealand. Posts can be considered defamatory. Recent reforms that enable the collection of metadata for national security reasons create dilemmas for social workers who may have to choose between disseminating information of public interest that they feel ethically obliged to disclose and being subjected to legal action and staying silent. This is of particular concern when social work values are directly contradicted by those of the state. For 
example, Australian health professionals who speak out about the institutional abuse of refugees where silence is compelled through legislation could be imprisoned.

Action in the Third Space also entails an awareness of other risks in online activities. Astroturfing, cyberbullying and flaming trolls exist and venturing online may attract them. Astroturfing is concept that describes marketing strategies where astroturfers are paid to pose as members of the public or grass root movements to manipulate comments, tweets and other online activities (Kolivos and Kuperman 2012). Flaming trolls are adept at intentionally entering conversations with the aim to inflame, disrupt and discredit those engaged in genuine dialogue and cyberbullies are those individuals who gain satisfaction from using bullying behaviours on others online (Herring et al. 2002). Researching about them and how to manage these situations if they occur is an important part of safe online activism.

Power, conflict, ethics, structural factors and a focus on deconstructing ideologies are core aspects of critical reflection and focal points in critical practice (Brookfield 2009; Fook 2002). According to Fook (2002) social workers have an uncomfortable relationship with conflict and power, particularly their own. Yet power and conflicts are unavoidable aspects of influence as are dealing with uncertainty and complex dilemmas. Utilising social work skills of reflection on our thoughts, motivations and ethical actions each time we intend to engage in online activism is central to maintaining the three Rs in the Third Space. Lorenzetti (2013) and Yerbury and Burridge (2013) emphasized the importance of reflexivity and an examination of biases and struggles in the formation of dual identities and activism also noted in Hessel’s (2011) manifesto. Identifying potential dilemmas and addressing them through reflection and supervision is as important and necessary online as in face-to-face interactions.

\section{Conclusion}


Hessel offered a framework to understand how despair, outrage, activism and hope work together and how peaceful civil disobedience can triumph over despair and outrage produced by injustice. Breaches of human rights, dehumanisation, racism and the marginalisation of some groups have reached new heights in neoliberal societies. The internet and a commitment to social work's mission and its core values that centre on human worth have enabled professional-activists to resist in new ways ranging from simply drawing attention to the wrongs in society creating organic connections to organised activism. The professionalactivist does not supersede traditional activism rather it adds a new dimension to social work identity and action. The hybrid identity of professional-activist in the Third Space enables social workers to transcend predetermined conceptualisations of their activism potential, provides opportunities to potentially influence others across, outward and upward, and to emerge from the subjectification of neoliberalism.

Activism in the Third Space adds new layers of complexity to ethical quandaries, not least where laws are passed to prevent social workers and others speaking out. Ethical dilemmas relate to confidentiality, dual responsibilities to employing agencies and the profession, engaging in ethical but illegal activity such as whistleblowing, the importance of critical reflection and supervision to ethical decision making and online activity, and social work values of human worth, upholding human rights and resisting injustice. Issues of safety cannot be ignored when negotiating ethical problems in attempts to bridge the chasm between competing obligations. As with all other social work practices, considerations of ethics, risk and responsibility involve reflections on power and agency, purpose and influence. We do need to understand engagement in the Third Space at a deeper level - how we negotiate and resolve complex ethical questions, and whether our efforts have real impact outside social work itself. Hessel describes how outrage must translate into action and a desire to engage. Social workers are engaging and acting in the third space but measuring actual impact as 
identified by McNutt (2006) is complex but not impossible. As such The Third Space offers a new frontier for research.

People are suffering in our societies. Outraged social workers have a voice and are increasingly committing peaceful civil disobedience legitimised by Hessel (2011). He hoped we would find our voices. Some authors like Reisch (2013) are hopeful for the future and the influence of social work while others are more pessimistic accepting the inevitability of subsumption by market-oriented politics (Lee 2014) but perhaps in Hessel's $(2011,11)$ words 'the worst attitude is indifference'. 


\section{References}

AUTHOR (2015)

AASW. 2015. Position Papers and Policy Statements. Accessed 28 May 2015.

http://www.aasw.asn.au/social-policy-advocacy/position-papers-and-statements

ACOSS. 2015. “Inequality in Australia: A Nation Divided”. In ACOSS (ed), Poverty and Inequality in Australia. NSW: Australian Council of Social Service.

Archer-Lean, C and H. Pavitt. 2012. "Politics and Ethics in Social Media”. Social Alternatives 31 (2): 3-5.

Armer, J and J Katsillis 2001. “Modernization Theory” In Encyclopedia of Sociology. 2nd ed. Vol. 3, 1883-1888. New York: Macmillan Reference USA.

Australian Human Rights Commission. 2014. The Forgotten Children: National Inquiry into Children in Immigration Detention (2014). Sydney: Australia.

Banks, S. 2012. “Global Ethics for Social Work? A Case-Based Approach”, In Practising Social Work Ethics around the World, edited by S. Banks and K. Nohr, 1 -31. Oxon, UK: Routledge.

Benthrup, W. 1964. “The Profession and the Means Test”. Social Work 9 (2): 10-17. 
Bhabha, H. 1990. “The Third Space: Interview with Homi Bhabba”. In Identity: Community, Culture, Difference, edited by Rutherford, J., 207-221. London: Lawrence and Wishart.

Brookfield, S. 2009. “The Concept of Critical Reflection: Promises and Contradictions”, European Journal of Social Work, 12 (3): 293 - 304.

Briskman, L., D Zion, D and B Loff. 2011. Care or Collusion in Asylum Seeker Detention. Ethics and Social Welfare, 6(1), 37-55.

Calhoun, A, M Wilson, and E Whitmore. 2014. “Activist Resistance in Neoliberal Times: Stories from Canada”. Critical and Radical Social Work 2 (2): 141-158.

Cooper, S. 1977. “Social work: a dissenting profession”. Social Work 22 (5): 360-367.

Congress, E. 2012. “Global Ethical Principles and Dilemmas” in Handbook of International Social Work: Human Rights, Development and the Global Profession, edited by L.Healy and R. Link, 297-304, New York, Oxford University Press.

Dean, W. R. 1977. “Back to Activism”. Social Work, 22(5): 369-373.

Deleuze, G. and F Guattari, F. 1981. "Rhizome”. Ideology and Consciousness, 8, 49-71.

Duncan-Daston, R, M Hunter-Sloan, and E Fullmer. 2013. “Considering the Ethical Implications of Social Media in Social Work Education”. Ethics and Information Technology 15 (1): 35-43.

English, L. 2005. “Third-Space Practitioners: Women Educating for Justice in the Global South”. Adult Education Quarterly 55 (2): 85-100. 
Fang, L, F Mishna, V Zhang, M Van Wert, and M Bogo. 2014. “Social Media and Social Work Education: Understanding and Dealing with the New Digital World”. Social Work in Health Care, 53(9): 800-814.

Farrell, P. (2015, July 1). Detention Centre Staff Speak out in Defiance of New Asylum Secrecy Laws. The Guardian. Retrieved $19^{\text {th }}$ June 2015 from http://www.theguardian.com/australia-news/2015/jul/01/detention-centre-staff-speakout-in-defiance-of-new-asylum-secrecy-laws

Ferguson, I., \& Lavalette, M. 2007. "Dreaming a Great Dream": Prospects for a New, Radical Social Work. Canadian Social Work Review / Revue canadienne de service social, 24(1): 55-68.

Flood, M, B Martin, and T Dreher. 2013. “Combining Academia and Activism: Common Obstacles and Useful Tools”. Australian Universities Review 55 (1):17-26.

Fook, J. 2002. Social Work: Critical Theory and Practice, Sage, London.

Frankl, V. 2004. A Man's Search for Meaning. UK: Rider, Ebury Publishing.

Garrett, P. M. 2008. “How to be Modern: New Labour’s Neoliberal Modernity and the Change for Children Programme”. British Journal of Social Work 38(2): 270-289. doi: 10.1093/bjsw/bcl345.

Gilbert, N. 2015. "Social Welfare Trends in Western Societies: Privatisation and the Challenge to Social Work”. Arbor 191 (771): a200. Retrieved from http://arbor.revistas.csic.es/index.php/arbor/article/view/2003/2427 
Gilens, M. 2012. Affluence and Influence: Economic Inequality and Political Power in America. New Jersey, USA: Princeton University Press and the Russell Sage Foundation.

Grant, W, B Moon, and J Grant. 2010. “Digital Dialogue? Australian Politicians' Use of the Social Network Tool Twitter”. Australian Journal of Political Science 45 (4): 579604.

Greenslade, L, D. McAuliffe, and L Chenoweth. 2014. “Social Workers’ Experience of Covert Workplace Activism”. Australian Social Work. Published on-line $14^{\text {th }}$ August 2014. doi:10.1080/0312407X.2014.940360.

Harris, J. 2014. “(Against) Neoliberal Social Work”. Critical and Radical Social Work 2 (1): $7-22$.

Healy, L. 2001. International Social Work: Professional Action in an Interdependent World. New York: Oxford University Press.

Herring, S, K Job-Sluder, R Scheckler and S Barab. 2002. “Searching for Safety Online: Managing "Trolling" in a Feminist Forum”. The Information Society 18 (5): 371-384.

Hessel, S. 2011. Time for Outrage. Indignez-vous! (M. Duvert, Trans.). New York, USA: Twelve Hachette Book Group.

Hessel, S. 2012. The Power of Indignation: The Autobiography of the Man who Inspired the Arab Spring (E. C. Belli, Trans.). New York, USA: Skyhorse Publishing.

Hills, J. 2015. Good Times, Bad Times: The Welfare Myth of Them and Us. Bristol, UK: Policy Press. 
Hübinette, T. 2004. “Adopted Koreans and the Development of Identity in the 'Third Space’”. Adoption \& Fostering 28 (1): 16-24.

Hugman, R. 2008. "Ethics in a World of Difference”, Ethics and Social Welfare, 2 (2): 11832.

Hutchins, B. (2014). The Many Modalities of Social Networking: The Role of Twitter in Greens Politics. Environmental Communication, 1-18.

IFSW. 2012. Refugees. Policy Statement. Accessed 28 May 2015. http://ifsw.org/policies/refugees/

Ioakimidis, V, I Martinez-Herrero, U Yanardağ, C Bennett, and D Teloni. 2013. “Austerity and Social Work in Europe: Listening to the Voices of Resistance”. Critical and Radical Social Work, 1 (2): 253-261.

Jones, O. 2011. Chavs: The Demonisation of the Working Class. London: Verso.

Jones, R. 2014. The story of Baby P: Setting the Record Straight. Great Britain: Policy Press.

Kahn, R., and D Kellner. 2004. New Media and Internet Activism: From the 'Battle of Seattle’ to Blogging. New Media \& Society, 6 (1): 87-95. doi:10.1177/1461444804039908.

Kerr, C. 2014. "Searching for the Fundamentals". Institute of Public Affairs Review: A Quarterly Review of Politics and Public Affairs 66 (3): 10-13.

Kimball, E, and J Kim. 2013. "Virtual Boundaries: Ethical Considerations for Use of Social Media in Social Work”. Social Work 58 (2): 185-188.

Kolivos, E, and A Kuperman. 2012. “Web of lies - legal implications of astroturfing”. Keeping Good Companies 64: 38-41. 
Lam, C, and H Tse. 2013. “Adversity and Resistance: Neoliberal Social Services and Social Work in Hong Kong”. Critical and Radical Social Work 1 (2): 267-271.

Lee, C. 2014. ”Conservative Comforts: Some Philosophical Crumbs for Social Work”. British Journal of Social Work 44 (8): 2135-2144.

Lewis, J. 2015. "Why social workers should address economic inequality”. The Social Work Helper. Accessed 26 May 2015. http://www.socialworkhelper.com/2015/05/26/socialworkers-address-economic-inequality/

Lorenzetti, L. 2013. Research as a Social Justice Tool: An Activist’s Perspective. Affilia, 28 (4): 451-457. doi:10.1177/0886109913505815.

McAuliffe, D. and L Chenoweth, L. 2008. “Leave No Stone Unturned: The Inclusive Model of Ethical Decision Making”. Ethics and Social Welfare, 2(1), 38-49.

McKendrick, D, and S Webb. 2014. “Taking a political stance in social work”. Critical and Radical Social Work 2 (3): 357-369.

McNutt, J. G. (2006). Building Evidence-Based Advocacy in Cyberspace. Journal of Evidence-Based Social Work, 3(3-4), 91-102.

Miragliotta, N. 2012. "Politicians, Twitter and the Limits of the Virtual Political Public Sphere”. Social Alternatives 31 (2): 6-10.

Mizrahi, T, and S Dodd. 2013. “MSW Students' Perspectives on Social Work Goals and Social Activism Before and After Completing Graduate Education”. Journal of Social Work Education 49 (4): 580-600. 
Morris, R. 2013. “'Unjust, Inhumane and Highly Inaccurate’: The Impact of Changes to Disability Benefits and Services - Social Media as a Tool in Research and Activism”. Disability \& Society 28 (5): 724-728.

Moth, R, J Greener, and T Stoll. 2015. “Crisis and Resistance in Mental Health Services in England”. Critical and Radical Social Work 3 (1): 89-101.

Muižnieks, N. 2015. "Female Poverty is on the Rise: Protecting Women's Rights”. The Social Work Helper. Accessed May 82015.

http://www.socialworkhelper.com/2015/05/08/female-poverty-rise-protectingwomens-rights/

Noble, C. and Briskman, L. 1996. “Social Work Ethics: Is a Moral Consensus Possible?”, Women in Welfare Education, 2: 51 -66.

Reamer, F. 2012. “The Digital and Electronic Revolution in Social Work: Rethinking the Meaning of Ethical Practice”. Ethics and Social Welfare 7 (1): 2-19.

Reeser, L. 1991. “Professionalization, Striving, and Social Work Activism”. Journal of Social Service Research 14 (3-4): 1-22.

Reisch, M. 2013. “What is the Future of Social Work”. Critical and Radical Social Work 1 (1): 67-85.

Robbins, S, and J Singer. 2014. "From the Editor-The Medium is the Message: Integrating Social Media and Social Work Education”. Journal of Social Work Education 50 (3): 387-390.

Robinson, K. 2014. "Voices from the Front Line: Social Work with Refugees and Asylum Seekers in Australia and the UK”. British Journal of Social Work 44 (6): 1602-1620. 
Routledge, P. 1996. “The Third Space as Critical Engagement”. Antipode 28 (4): 399-419.

Shields, B. (2015, January 5). Abbott government spends up big on monitoring social media. The Sydney Morning Herald. Retrieved from http://www.smh.com.au/federalpolitics/political-news/abbott-government-spends-up-big-on-media-monitoring20150104-12hj88.html

Schraer, R. 2015. “'I'm a Social Worker Because': Practitioners Tell the World Why They Do It”. Community Care. Accessed 28 May 2015. http://www.communitycare.co.uk/2015/05/26/im-social-worker-practitioners-tellworld/

Smart, C. 1989. “The Problem with Rights”. 138-159 In Feminism and the Power of the Law. New York: Routledge.

Smith, L. 2015. "What Should Social Work Learn from 'the Fire of Social Movements that Burns at the Heart of Society'?” Critical and Radical Social Work 3 (1): $19-34$.

Soon, C and R Kluver. 2014. "Uniting Political Bloggers in Diversity: Collective Identity and Web Activism”. Journal of Computer-Mediated Communication 19 (3): 500-515.

Swank, E. 2012. "Predictors of Political Activism among Social Work Students”. Journal of Social Work Education 48 (2): 245-266.

Turbett, C. 2013. Radical Social Work in the Frontline: A Survival Toolkit for the UK. Critical and Radical Social Work 1 (2): 225-232.

United Nations. 1948. Universal Declaration of Human Rights. Accessed 28 May 2015. http://www.un.org/en/documents/udhr/index.shtml

Vigneswara Ilavarasan, P. 2013. “Community Work and Limited Online Activism Among India Youth”. The International Community Gazette 75 (3): 284-299. 
Weiss, I. 2003. "Social Work Students and Social change: on the Link between Views on Poverty, Social Work Goals and Policy Practice”. International Journal of Social Welfare 12 (2): 132-141.

Whitchurch, C. 2008. "Shifting Identities and Blurring Boundaries: The Emergence of Third Space Professionals in UK Higher Education”. Higher Education Quarterly: 62 (4), 377-396.

Wilkinson, R, and K Pickett. 2010. The Spirit Level: Why Equality is Better for Everyone. London UK: Penguin.

Williams, C, and L Briskman. 2015. "Reviving Social Work through Moral Outrage”. Critical and Radical Social Work 3 (1): 3-17.

Williamson, A. (2010). Politicians get their Clicks. The World Today 66 (2): 14-16.

Yerbury, H, and N Burridge. 2013. “The Activist Professional: Advocacy and Scholarship”. Third Sector Review 19 (2): 119-134 